\title{
Evaluation Of The Profitability Of Companies Financed By Venture Capital (CVC) Listed On The French Market
}

Moez Khalfallah, University of Cergy Pontoise, France

Bruno-Laurent Moschetto, University of Valenciennes, France Frédéric Teulon, IPAG Business School, France

\begin{abstract}
This paper examines changes in profitability of 146 CVC listed on the French market. The results show disappointing post-IPO profitability. The decline in performance ranges from $9.5 \%$ to $32 \%$ over a two-year period following the launch on the stock exchange. It also appears that the decline in operating performance is less significant for CVC compared with non CVC over the same period. An analysis of this underperformance shows that CVC supported by reputed VCF manage to limit the decline in operating performance compared to those supported by nonreputed VCF.
\end{abstract}

Keywords: Companies Financed by Venture Capital (CVC); Venture Capital Firms (VCF); Return on Assets (ROA); Corporate Reputation

\section{INTRODUCTION}

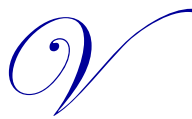

enture capital is central to start-up funding and to the development of upcoming industrial sectors (biotechnologies, nanotechnologies, Internet applications...). This type of funding is directly linked to the real economy and it can expand the process of value creation (Tian, 2012). The IPO marks a key stage in this type of funding (Hall \& Lerner, 2010; Mulcahy, 2013). In contrast, large established firms do appear to prefer internal funds for financing their investments and they manage their cash flow to ensure this.

Studies on the profitability of firms financed by venture capital (CVC) following an IPO remains few and far between on the American market and even more so for the European market. However, the few studies that do exist note a decline in the operational performance of firms in the immediate aftermath of the IPO. Jain \& Kini (1995), Ivanov et al. (2009), Lantz et al. (2011) on the American market, as Harris et al. (2006) and Wood et al. (2007) on the UK market, confirm the decline in profitability following the firm's IPO compared to its pre-flotation level. The extent and the robustness of results regarding the underperformance of listed firms led the authors to conclude that the managers had taken advantage of their knowledge of the market to launch their companies during bullish market trends.

Ivanov (2009) examines the operational performance of $830 \mathrm{CVC}$ listed on the American market between 1981 and 2000. He identifies a decline in operational performance following the IPO. However, he shows that the presence of a venture capital firm in the company's share structure has a positive impact on the operational performance of CVC following the launch on the market. He also finds that a higher degree of commitment by the VCF resulted in greater profitability.

On the British market, Wood et al. (2007) analysed the profitability of 316 CVC and 274 non CVC listed on the stock exchange between 1985 and 2003. They concluded that there was a decline in operational performance during a 5-year period following listing. They noted that the operational underperformance of CVC was concentrated in the 1998-2000 Internet bubble years. In effect, including the financial crisis period in a study's timeframe appears to have a considerable impact on the CVCs' decline in performance. However, Harris et al. 
(2006) found a non significant difference between the performance of CVC and non CVC pre- and post-IPO on the British market. On the other hand, CVC supported by reputed VCF outperformed CVC supported by non-reputed VCF. These results are in line with the conclusions by Wright et al. (2002) who identified a positive correlation between the age of the VCF and the performance of listed firms.

To gain more insight into changes in profitability of firms listed on the European markets, Rindermann (2003) selected a sample of 154 CVC newly listed on the French, German and British markets. Overall, the author corroborated the decline in performance for all markets. In addition, national VCF appear to have a positive impact on newly listed CVC.

The paper begins with a review of the literature. The second section focuses on the methodology and hypotheses. The third section presents the sample population used for the study and the tests performed, while the fourth section presents the results of univariate tests. The fifth section explains the determinants of the operational performance of CVC listed on the French market, and the last section concludes.

\section{METHODOLOGY AND HYPOTHESES}

\section{Methodology}

The aim of the present article is to propose measurements of variations in operational performance in the context of CVC listed on the French market, and then to explain their evolution in the post-IPO period.

We began by selecting a sample population of 146 CVC listed on the French market between 1996 and 2007 (before the financial crisis). We paired each firm in the sample with a benchmark firm based on sectorial and temporal criteria, and then selected profitability as an operational performance indicator. First, we checked the decline in the performance of CVC following the IPO. We then tested the difference in performance between CVC and non CVC using the Wilcoxon non parametric test. We then identified the determinants of the operational performance of CVC.

The results of the univariate analysis in median value based on static data confirm the decline in performance which is between $9.47 \%$ and $31.97 \%$ over the period $[-1 ; 2]$. The Wilcoxon non-parametric signed-rank test shows a significant difference around the time of the launch. We also noted that the presence of a reputable VCF in the capital of CVC at the time of listing improves the latter's performance compared to CVC supported by nonreputed VCF. On the other hand, we corroborated the negative impact of the flotation period on profitability, which could be explained by an effect of timing. A cross-sectional regression model was used to validate the results.

While the nature of firms is different from one study to another, the research hypothesis remains the same. The last hypothesis is as follows: "the nature of business organisations (both CVC and non CVC) generates specific operational performance following an IPO." To check this hypothesis, we conducted a two-stage operation. First, we selected the operational performance indicators and we then identified the most suitable tests in order to test the significance of operational performance.

A review of the finance literature investigating operational performance reflects wide diversity in the choice of indicators used to assess changes in the process. Most studies on the profitability of newly listed firms take profitability as the key indicator. This is based on the English notion of EBITDA. ${ }^{1}$ Opting to use EBITDA meant that we avoided the impact of mechanical leverage on the results.

To compare the performances of firms, we had to standardize EBITDA. We calculated the profitability ratio as follows: EBITDA/total assets. This ratio is mentioned by the majority of studies in line with Jain \& Kini (1994), Ivanov (2009), and Harris et al. (2006). The measure is called 'Return On Asset' (ROA).

Two methods were used to test the hypothesis. First, we conducted a univariate analysis based on the Wilcoxon non parametric rank-sum test. This test is used to compare the characteristics of two distributions or

${ }^{1}$ Earnings before Interest, Taxes, Depreciation, and Amortization 
samples. It represents a non parametric alternative to the Student test $t$, based uniquely on the order of observations from two samples. The test can provide relevant answers to questions of form: Is there a significant difference in the central trends of two distributions? Secondly, we carried out multivariate analyses.

\section{Hypotheses}

\section{Decline in Profitability}

According to traditional theory, there is no reason that a company making the transition from private to public ownership experiences a fall in profitability compared to that of the year prior to the IPO. In effect, the flotation should improve profitability due to the increase in capital and market authority controls. However, prior research confirms a drop in profitability, especially post-IPO.

In line with Jensen \& Meckling (1976), we could argue that one explanation for the operational underperformance in the long term may be found in agency theory (i.e. the IPO is at the origin of an increase in agency costs). Jung, Kim, \& Stulz (1996) suggest that the managers tend to focus more on growing their business, and that the market's negative reaction to the flotation announcement is a reflection of managers' priority to increase the size of their business rather than to maximise shareholders' wealth. This leads us to hypothesis 1 :

$\mathbf{H}_{1}$ : $\quad$ Firms experience a decline in their operational performance following an IPO.

The Role of Venture Capital Firms (VCF)

Some studies have compared the pre- and post-listing performance of CVC and non CVC. Jain and Kini (1995), for instance, argue that VCF in the USA maintain their support and actively survey their CVC portfolio during the post-IPO period.

In the long run, VCF want the IPO to be a success and continue to provide the support needed to ensure the CVC performs well on the stock market, thus enabling them to forge a good reputation (Lerner, 1994b). The same observations have been made on the British market (Espenlaub et al., 2001). From this, we can infer that CVC should outperform non CVC following an IPO, and even if the performance of both CVC and non CVC declines during the post-IPO period, the fall recorded by the CVC will be less significant (Jain \& Kini, 1995). On the other hand, Rinderman (2003) notes that CVC introduced on the German, French and British markets are no more successful than non CVC. However, the difference in performance observed on the US markets could be explained by the experience and the management styles used by American VCF (Landier, 2001; Hege et al., 2003). Given the elements mentioned above, our second hypothesis is as follows:

$\mathbf{H}_{2}$ : The difference in profitability between $\mathrm{CVC}$ and non CVC following an IPO is insignificant.

\section{The 'Market Timing' Period}

The decline in profitability is also coherent with the 'timing' theory. According to this hypothesis, managers manipulate the date of an increase to make it coincide with a particularly favourable moment (Loughran \& Ritter, 1997). In effect, they note that managers choose to issue shares after an increase in stock prices, and that investors are unable to value the firms correctly at the time of the IPO. They conclude that some issuing firms, although not all, deliberately and successfully mislead investors. The sentiments based on overvalued shares tend to be stronger during so-called 'hot' market periods such as the internet bubble between 1998 and 2000 (Ofek \& Richardson, 2002).

The question now is to know whether, in this context, the support of highly experienced VCF who benefit from greater expertise than the market can immunise CVC against the negative impact of market conditions. If this hypothesis is correct, we should observe a smaller decline in the profitability of CVC compared to non CVC during a bullish market period. We can thus formulate hypothesis $\mathrm{H}_{3}$ :

$\mathbf{H}_{3}$ : $\quad$ CVC recorded higher profitability post-IPO than non CVC at the time of the Internet bubble. 
The Reputation of VCF

Many authors have identified heterogeneity of experience and competencies of VCF that provide CVC with support in the initial stages of development (Timmons \& Bygrave, 1986; Rindermann, 2003, Ivanov et al., 2009). Reputed VCF appear to be able to attract and select good quality firms and provide greater added value, which has a positive impact on the global performance of their corporate portfolio. However, research conducted to this end on the different markets is inconclusive about whether there is a positive link between a VCF's reputation and the performance of CVC following an IPO.

Sapienza et al. (1996) and Manigart et al. (2002) argue that experienced VCF play a key role in providing their corporate portfolio with added value compared to inexperienced VCF. With regard to long-term market performance, Espenlaub et al. (1999) found that CVC generate a very slightly better performance compared to non CVC. However, firms supported by reputed VCF reported better performance compared to firms supported by non reputed VCF. This difference in post-IPO performance is linked to the reputation and experience of VCF. Ivanov et al. (2009) identified the impact of the VCF's reputation on the performance of CVC listed on the stock market using an approach based on instrumental variables. They suggest that not only do the most highly reputed VCF support the post-IPO development of their corporate portfolio, but that this also leads to an improvement in the companies' long-term performance.

To test the impact of the reputation of VCF on CVC profitability, we put forward the fourth hypothesis:

$\mathbf{H}_{4}$ : $\quad$ CVC supported by reputed VCF report better post-IPO operational performance than CVC supported by non-reputed VCF.

\section{Initial Return}

Jain and Kini (1994) used signalling theory to argue that firms with an initially low (or even negative) return put out a positive signal. This signal is reflected through improved profitability of the firms following an IPO. The hypothesis is based on the signalling theory developed by Allen \& Faulhaber (1989), Grinblatt \& Hwang (1989) and Welch (1989). They argue that the low value of firms reduces the additional costs involved to check the true value of listed firms as would be the case with large firms. Krigman et al. (1999), however, use the behavioural approach to explain the inverse relation between initial returns and long-term profitability. In effect, they argue that an IPO with high initial returns is likely to be affected by a sentiment of investor aversion, reinforcing the decline in post-IPO profitability. However, investigating a sample of $316 \mathrm{CVC}$ listed on the British market, Wood et al. (2007) rejected the signalling hypothesis put forward by Jain \& Kini (1994) in normal periods but corroborated it during the bubble years. We suggest that the signalling theory is confirmed for $\mathrm{CVC}$, which brings us to hypothesis $\mathrm{H}_{5}$ :

$\mathbf{H}_{5}: \quad$ There is an inverse relation between the initial returns of CVC and profitability following an IPO.

\section{The High-Tech Sector}

Ofek \& Richardson (2002) developed a study framework inspired by the work of Miller (1977) to show that irrational investor behaviour took hold of the market during the Internet bubble years. This resulted in unrealistic overvaluations, principally in the high-tech sector. In effect, we noted that a large percentage of the CVC in our sample belong to the high-tech sector. This led us to check if the CVC listed in the high-tech sector reported a greater decline in profitability than the benchmark firms listed in the same sector.

$\mathbf{H}_{6}$ : $\quad$ CVC listed in the high-tech sector report greater operational underperformance than non CVC.

\section{DEFINITION OF SAMPLE AND DESCRIPTIVE STATISTICS}

\section{Data Collection}

We identified all of the firms financed by venture capital listed on the French market between 1996 and 2007, in other words, 184 firms. We then took out all firms that were taken over or merged following the IPO. 
Finally, all firms that did not report at least two financial years for the IPO study report were also excluded. Our final study thus included a reduced sample of 146 CVC.

The data relative to our sample was collected from several databases. The list of CVC and the accounting information and characteristics of firms were collected from VentureXpert, Thomson Financial, Datastream, and Worldscope bases. The missing data in reports of certain observations were completed from the specialised Diane database. However, the data taken from these different sources were processed so as to homogenise them.

\section{Benchmark Sample}

In order to highlight the operational performance of newly listed CVC, we used a benchmark sample comprising firms financed by traditional means and listed on the French market, which we called 'non CVC.' In the context of the present study, we adopted the methodology developed by Barber \& Lyon (1996), pairing each of the CVC in our sample with a non CVC using the following criteria ranked by order of priority: sectorial criteria, temporal criteria, and size criteria.

We chose the benchmark firms from companies belonging to the same sector of activity as the CVC. The activity sector definition was made according to the American classification based on the 4-figure SIC $^{2}$ code (see Ritter, 1991; Ivanov, 2009). In cases where there were not enough firms with these criteria, we took a 3 or even 2figure SIC code (in fact, in our study, $89 \%$ of the benchmark firms were selected using the 4-figure SIC code). Adopting this approach enabled us to rule out intra-sectorial variations and temporal bias on the results.

\section{The Reputation of VCF}

The study of the impact of the reputation of VCF on the long-term performance of listed firms has been widely covered in the finance literature. Ivanov et al. (2009) used the market share of VCF that had successfully floated the IPO ${ }^{3}$ market share of their CVCs as a measure of reputation. This is similar to assessing reputation by the success rate of VCF as suggested by Megginson \& Weiss (1991). Nahata (2008) adopted cumulated market share and showed that a VCF with a better will enhance the flotation of CVC. Gompers (1996) suggests the age of the $\mathrm{VCF}$ as an indicator of reputation as it reflects greater experience in corporate finance. Lee \& Wahal (2004) combine the age of VCF and the number of listed CVC to measure reputation. Gompers \& Lerner (1999) also argue that the amount of capital raised by VCF is a good indicator of their reputation.

Jelic et al. (2005) and Harris et al. (2006) measured the reputation of VCF by the number of finance operations, arguing that a reputable VCF must have at least 3\% of the British market in terms of number of transactions between 1980 and 1997. In the light of this study, we identified the total amounts invested by VCF in CVC successfully launched on the stock market in the period 1980-2007. We then ranked the VCF according to their market share in decreasing order. Thus, reputed VCF belong to the ten leading firms in our ranking. ${ }^{4}$ It should be noted that when confronted with a consortium of VCF, we measured reputation by using the second method proposed by Ivanov et al. (2009), namely the reputation of the investor who owns the largest share of the CVC capital at the time of the IPO (see appendix).

\section{Descriptive Statistics}

Given the specificity of our sample, the following section gives a more detailed account of the information relative to our observations (CVC and non $\mathrm{CVC}$ ). Table 1 presents a summary of the characteristics of the global sample divided between CVC and non CVC for the financial year of the IPO. The size of the sample CVC is far greater in terms of turnover, total assets, liabilities and stock market capitalization compared to the benchmark firms (non CVC). Thus, Panel A shows that the CVC make a median turnover of 26.3 against 12.7 (more than 2 times) that of non CVC. This difference is confirmed by the significance of the Wilcoxon test at a threshold of $1 \%$.

\footnotetext{
${ }^{2}$ Standard Industrial Classification

${ }^{3}$ Initial Public Offering

${ }^{4}$ The ten leading VCF also correspond to firms with at least 3\% of market share.
} 
Similarly, the median value of CVC market capitalization, total assets and liabilities is far greater than for non CVC. This difference is significant at the 5\% threshold. These results are in line with the conclusions of Lin \& Smith (1998), Megginson \& Weiss (1991) and Wood et al. (2007), who also found significant differences in assets, liabilities and market capitalization for the sample CVC and the benchmark sample.

The comparison of median values of total operational/assets result ratios and net/total asset results indicates that CVC use their capital less efficiently than the benchmark firms. The Wilcoxon test shows that this difference is significant at a threshold of $1 \%$ (see Panel B). These results concur with the findings of Wood et al. (2007). Moreover, the median value of the total ratio of liabilities/assets for the CVC is greater than for the sample of non CVC.

Table 1: Characteristics of the Sample of CVC Listed on the French Market between 1996 and 2007

\begin{tabular}{|c|c|c|c|c|}
\hline & $\begin{array}{l}\text { Sample } \\
\text { Median } \\
\end{array}$ & $\begin{array}{c}\text { EVC } \\
\text { Median } \\
\end{array}$ & $\begin{array}{c}\text { Non EVC } \\
\text { Median } \\
\end{array}$ & $\begin{array}{c}\text { Wilcoxon Signed- } \\
\text { Rank Test } \\
\end{array}$ \\
\hline \multicolumn{5}{|c|}{ Panel A: IPO's Characteristics } \\
\hline Number of observations & 292 & 146 & 146 & - \\
\hline Age & 10 & 9 & 11 & $-0,453$ \\
\hline Turnover $(\mathrm{M} €)$ & 17,7 & 26,3 & 12,9 & $3,021^{\mathrm{a}}$ \\
\hline Total asset $(\mathrm{M} €)$ & 24,5 & 30,5 & 16,4 & $2,724^{\mathrm{a}}$ \\
\hline Debts $(\mathrm{M} €)$ & 9,3 & 12,1 & 6,5 & $2,854^{\mathrm{a}}$ \\
\hline Return on assets & 1,6 & 1,7 & 1,4 & 0,518 \\
\hline Net return $(\mathrm{M} €)$ & 0,9 & 1,2 & 0,9 & 0,565 \\
\hline Net return adjusted* $(\mathrm{M} €)$ & 1,0 & 1,2 & 0,9 & 0,486 \\
\hline Earnings per share & 0,4 & 0,3 & 0,4 & $-1,579$ \\
\hline Book to market per share & 3,5 & 3,7 & 3,4 & $-0,454$ \\
\hline Market value $(\mathrm{M} €)$ & 41,7 & 59,2 & 30,5 & $2,302^{\mathrm{b}}$ \\
\hline \multicolumn{5}{|l|}{ Panel B: Ratios en (\%) } \\
\hline Turnover/Total asset & 92,20 & 89,80 & 94,90 & 0,197 \\
\hline Debts/Total asset & 53,48 & 55,41 & 51,64 & $2,691^{\mathrm{a}}$ \\
\hline Return on assets / Total asset & 6,34 & 5,77 & 6,55 & $-2,744^{\mathrm{a}}$ \\
\hline Net return/Total asset & 4,28 & 3,65 & 5,04 & $-2,455^{\mathrm{b}}$ \\
\hline Net return*/Total asset & 4,29 & 3,63 & 5,04 & $-2,809^{\mathrm{a}}$ \\
\hline
\end{tabular}

After describing the characteristics of our sample in the year of the IPO as well as that of the benchmark firm, we will now discuss the different hypotheses presented above.

\section{UNIVARIATE ANALYSIS}

In the context of the present study, we conducted a series of tests on the statistical data needed for each of these hypotheses. In line with the work by Loughran \& Ritter (1997), Wood et al. (2007) and Harris et al. (2006), we decided to use the median value to estimate key trends. In effect, unlike average value, the median value places less weight on observations. ${ }^{5}$

We used the Wilcoxon signed-rank test to test the hypothesis that the median variation of the operational performance ratio level during the pre-IPO and post-IPO periods on the French market, for CVC and non CVC, follows an identical distribution. A positive (negative) difference in median value indicates that the CVC experienced a favourable (unfavourable) change in the level of operational performance ratios compared to non CVC. The level of performance in the previous financial year and that of the year of the IPO are used as a reference.

\footnotetext{
${ }^{5}$ It is well known that accounting ratios are subject to problems of skewness (Loughran \& Ritter (1997). Several authors (Mikkelson et al., 1997; Sentis, 2011; Wood et al., 2007; Harris et al., 2006) prefer to use the median to estimate key trends.
} 
The Panel C study the median values of profitability of listed CVC for the period $[-1 ; 2]$. It is clear that profitability is highest in the year preceding the IPO (7.17\%) and that it declines steadily in the years following the flotation. These results appear to confirm the hypothesis of a decline in operational performance of CVC post-IPO. Moreover, the comparison of changes in operational performance measured by profitability shows similar results for the CVC sample and the non CVC. However, the difference in performance between CVC and non CVC indicates better performance by the benchmark firms in the year of flotation and the following year. Thus, the profitability of newly listed CVC is below $4.05 \%$ and $0.83 \%$ respectively for the year (0) and (1) compared to non EVC. In line with the conclusions of Harris et al. (2006), we note that the CVC outperform the benchmark firms in year (2). On the other hand, the Wilcoxon test shows that the difference in performance in median value is non significant between the CVC and non CVC post-IPO. These observations enable us to validate hypothesis $\mathrm{H}_{2}$.

For Panel D, the profitability of CVC shows a median increase between year (-1) and year (0), followed by a decline in the remainder of the study period. On the other hand, compared with the benchmark firms, the profitability of CVC listed during the bubble years displays a positive difference in the two years following the IPO, while nonetheless remaining statistically insignificant. We also noted a negative and statistically significant difference during year (-1) and year (0). These results corroborate the conclusions of studies by Mikkelson et al. (1997) and Wood et al. (2007), respectively concerning the American and British markets.

Thus we identified a decline in the operational performance of CVC listed during the bubble years. However, CVC record a post-IPO operational performance higher than non CVC during the bubble period uniquely in year (2), but it is nonetheless non significant. These results concur with those of Wood et al. (2007) which noted the absence of significant operational performance of CVC listed on the British market during the Internet bubble years. We can thus reject hypothesis $\mathrm{H}_{3}$.

To study the impact of the reputation of VCF present in the capital of CVC on post-IPO profitability, we divided our sample of CVC into two groups: CVC supported by reputed VCF (43 firms) and CVC supported by non-reputed VCF (102 firms). For Panel E, the profitability of reputed CVC falls following an IPO from 10.92 to $8.06 \%$ in year (2). This is confirmed by the presence of a positive and statistically significant difference between the reputed CVC and the non-reputed CVC in the post-IPO period. This difference in performance tends to gradually recede from year (2). From the results of the profitability distribution of CVC according to the reputation of VCF, we can confirm the conclusions of Harris et al. (2006) and Rindermann (2003). In effect, these authors argue that the underperformance of CVC listed on the different stock markets is closely linked to the reputation of VCF leaders. Thus, the presence of reputed VCF in the capital of listed CVC reduces the decline in profitability (Hellmann \& Puri, 2002; Ivanov, 2009).

In short, CVC supported by reputed VCF tend to do better during the IPO than CVC supported by nonreputed VCF, which confirms hypothesis $\mathrm{H}_{4}$.

Several studies, including those by Ofek \& Richardson (2002) and Wood et al. (2007), found a link between operational underperformance and the high-tech sector. To check this hypothesis, we divided our sample into 3 sectors. Panel F shows that the comparison in operational performance of CVC and non CVC from the hightech sector indicates a negative difference in all of the study periods. However, this difference is significant for year (0) and (1). This finding supports hypothesis $\mathrm{H}_{5}$ which stipulates that CVC listed in the high-tech sector display greater operational underperformance than non CVC. Regarding other market sectors, we firstly observed that listed industrial CVC do better than the listed benchmark firms. At the same time, there is a non significant negative median value difference in the profitability of CVC listed in the service sector compared to non CVC. In the light of the results obtained, we confirm the underperformance of CVC in the high-tech sector compared to non CVC listed in the same sector. Our findings are in line with the conclusions of Wood et al. (2007) for the British market.

To analyse the impact of the reputation of VCF present in the capital of CVC on profitability following an IPO, we divided our sample of CVC into two groups: CVC supported by reputed VCF (43 firms) and CVC supported by non-reputed VCF (102 firms). Panel E shows that following an IPO, the profitability of reputed CVC declines from $10.92 \%$ before the IPO to $8.06 \%$ in year (2). This is confirmed by a positive and statistically significant difference between reputed CVC and non-reputed CVC in the post-IPO period. This difference in 
performance tends to gradually die out from year (2). The results of the distribution of operational performance of CVC according to the reputation of VCF correlates with the conclusions of Harris et al. (2006) and Rindermann (2003) who show that the underperformances of CVC listed on the different stock markets is closely related to the reputation of VCF leaders. Thus, the presence of reputed VCF in the capital of newly listed CVC reduces the decline in profitability (Hellmann \& Puri, 2002; Ivanov, 2009).

In short, CVC launching an IPO and supported by reputed VCF tend to do better than CVC supported by non-reputed VCF, thus confirming hypothesis $\mathrm{H}_{4}$.

Several studies, including those by Ofek \& Richardson (2002) and Wood et al. (2007) identified a link between operational underperformance and the high-tech sector. To check this hypothesis, we divided our sample into 3 sectors. For Panel F, the comparison of the operational performance of CVC and non CVC from the high-tech sector shows a negative difference for all the periods under study. The difference is significant for years (0) and (1). This result supports hypothesis $\mathrm{H}_{5}$ which stipulates that $\mathrm{CVC}$ listed on the high-tech sector show greater operational underperformance compared to non CVC. Regarding the other market sectors, we observed, firstly, the superiority of industrial CVC compared to the benchmark firms launched on the stock market, and secondly, the CVC listed in the services sectors present a negative median value and non significant difference in profitability compared to non CVC. In view of these findings, we confirm the underperformance of CVC from the high-tech sector compared to non CVC listed in the same sector. Our conclusions are in line with those of Wood et al. (2007) on the British market.

Table 2: Profitability of CVC and Non CVC Listed on the Stock Exchange in the Period [-1, 2]

\begin{tabular}{|c|c|c|c|c|}
\hline & \multicolumn{4}{|c|}{ Médian (\%) } \\
\hline & Year $(-1)$ & Year $(0)$ & Year (1) & Year (2) \\
\hline \multicolumn{5}{|c|}{ Panel C: EVC/non EVC } \\
\hline EVC & 7,17 & 6,54 & 5,28 & 5,43 \\
\hline non EVC & 9,45 & 6,55 & 5,18 & 3,44 \\
\hline wilcoxon & $-3,196^{\mathrm{a}}$ & $-2,917^{\mathrm{a}}$ & $-1,263$ & 1,006 \\
\hline Number of EVC & 140 & 137 & 132 & 119 \\
\hline \multicolumn{5}{|c|}{ Panel D: Buble Effect } \\
\hline non buble EVC & 8,49 & 6,96 & 6,38 & 7,46 \\
\hline non buble non EVC & 9,79 & 6,44 & 7,83 & 5,30 \\
\hline wilcoxon & $-2,189^{a}$ & $-1,805^{\mathrm{c}}$ & $-1,364$ & 0,608 \\
\hline buble EVC & 4,74 & 6,13 & 5,14 & 4,32 \\
\hline buble non EVC & 8,97 & 6,69 & 3,99 & 3,16 \\
\hline wilcoxon & $-1,925^{\mathrm{c}}$ & $-1,671^{\mathrm{c}}$ & $-0,343$ & 0,703 \\
\hline \multicolumn{5}{|c|}{ Panel E: Reputation of SCR } \\
\hline Reputable SCR & 10,92 & 9,56 & 9,06 & 8,06 \\
\hline Non reputed SCR & 5,50 & 5,21 & 2,23 & 4,52 \\
\hline wilcoxon & $2,491^{\mathrm{b}}$ & $2,76^{\mathrm{a}}$ & $2,931^{\mathrm{a}}$ & $2,01^{\mathrm{b}}$ \\
\hline \multicolumn{5}{|c|}{ Panel F: Sector Effect } \\
\hline High-tech EVC & 4,51 & 4,93 & 2,23 & 4,19 \\
\hline High-tech non EVC & 10,10 & 7,26 & 5,75 & 2,73 \\
\hline Wilcoxon & $-3,797^{a}$ & $-3,163^{\mathrm{a}}$ & $-2,314^{\mathrm{b}}$ & $-0,564$ \\
\hline Industry EVC & 9,60 & 8,54 & 9,15 & 8,16 \\
\hline Industry non EVC & 7,75 & 5,52 & 0,73 & 1,30 \\
\hline Wilcoxon & 0,355 & 0,093 & $2,643^{\mathrm{a}}$ & $2,832^{\mathrm{a}}$ \\
\hline Services EVC & 8,90 & 7,08 & 5,90 & 5,01 \\
\hline Services non EVC & 10,46 & 6,64 & 8,05 & 7,50 \\
\hline Wilcoxon & $-0,087$ & $-0,226$ & $-0,7$ & 0,03 \\
\hline
\end{tabular}




\section{DETERMINANTS OF OPERATIONAL PERFORMANCE OF CVC}

\section{Regression Variables}

In this section, we examine the factors likely to affect the operational performance of CVC following an IPO. To this end, we performed multivariate analyses using regression models. Our aim is to highlight the relative importance of each of the explanatory variables in the decline in CVC performance. We used the operational result deflated by the total of assets observed as a dependant variable for the global sample in the initial stages, then for the sample of CVC. To pursue this study further, we assessed these regressions in different periods (years 0,1 and 2).

The explanatory variables concern firstly the variable (VC) which indicates whether the firm is financed by VCF or not, in line with Wood et al. (2007) and Rindermann (2003). Hypothesis $\mathrm{H}_{4}$ suggests there is a link between the reputation of VCF and the operational performance of CVC. Thus, we introduce a variable into the model that expresses the reputation of VCF (see Ivanov et al., 2009).

We also introduce traditional variables collected from the finance literature that can explain operational performance as a control. These variables describe the firm's ex-ante uncertainty, which is negatively linked to the newly listed firm's stock market performance. Ex-ante uncertainty may be described by the financial leverage, the firm's size (approximated by market value) and the degree of the initial undervaluation (RI). The market conditions constitute another control variable. According to Loughran \& Ritter (1995) and Wood et al. (2007), firms listed during so called 'hot market' periods report performances that are less profitable in the long term compared to firms listed in normal years. In the context of our study, the 'hot market' corresponds to the Internet bubble years. In line with Wood et al. (2007), we use the rate of asset turns to capture the impact of turnover deflated by total assets made before the IPO on post-IPO profitability.

The regression model used for the multivariate analysis was based on the work by Wood et al. (2007), Ivanov (2009), Rindermann (2003), and may be presented as follows:

$\mathrm{RE}_{\mathrm{i}}=\beta_{0 \mathrm{i}}+\beta_{1 \mathrm{i}} \mathrm{RI}_{\mathrm{i}}+\beta_{2 \mathrm{i}} \operatorname{LnAge}_{\mathrm{i}}+\beta_{3 \mathrm{i}} \mathrm{LnVM}_{\mathrm{i}}+\beta_{4 \mathrm{i}} \mathrm{LnBTM}_{\mathrm{i}}+\beta_{5 \mathrm{i}}$ Leverage $_{\mathrm{i}}+\beta_{6 \mathrm{i}} \mathrm{RA}_{\mathrm{i}}+\beta_{7 \mathrm{i}} \mathrm{HT}_{\mathrm{i}}+\beta_{8 \mathrm{i}} \mathrm{IND}_{\mathrm{i}}+\beta_{9 \mathrm{i}} \mathrm{BUB}_{\mathrm{i}}$

\section{Summary of Results and Interpretation}

Firstly, we observe that the initial return (IR) has a negative and significant impact on profitability over the course of the year of flotation. In effect, an initial overvaluation appears to explain the decline in profitability during the public company's first year, at least in part. However, the impact of the initial return is less important in the performance of CVC (-2.5\% for CVC against $-12 \%$ for the overall sample). This result supports hypothesis $\mathrm{H}_{5}$ and is in line with the conclusions of Krigman et al. (1999) and Wood et al. (2007) which state that an IPO with a significant initial return is likely to see a decline in performance in the post-IPO period.

Table 3: Determinants of Post-IPO Operational Performance

\begin{tabular}{|c|c|c|c|c|c|c|c|}
\hline \multirow{2}{*}{ Independent Variables } & \multirow{2}{*}{ Expected Sign } & \multicolumn{2}{|c|}{ Year (0) } & \multicolumn{2}{|c|}{ Year (1) } & \multicolumn{2}{|c|}{ Year (2) } \\
\hline & & Spécif. 1 & Spécif. 2 & Spécif. 1 & Spécif. 2 & Spécif. 1 & Spécif. 2 \\
\hline \multirow[t]{2}{*}{ Constant } & & $-0,012$ & $-0,164^{\mathrm{c}}$ & $-0,035$ & $-0,197^{\mathrm{c}}$ & $-0,103$ & $-0,116$ \\
\hline & & $(-0,25)$ & $(-1,97)$ & $(-0,74)$ & $(-2,27)$ & $(-1,68)$ & $(-1,08)$ \\
\hline \multirow{2}{*}{ RI } & - & $-0,120^{\mathrm{c}}$ & $-0,025^{\mathrm{b}}$ & $-0,100$ & $-0,169$ & 0,214 & 0,283 \\
\hline & - & $(1,87)$ & $(-2,14)$ & $(-0,85)$ & $(-0,99)$ & $(1,46)$ & $(1,39)$ \\
\hline \multirow{2}{*}{ LnAge } & & $0,005^{\mathrm{b}}$ & $0,018^{\mathrm{b}}$ & $0,030^{\mathrm{a}}$ & $0,039^{\mathrm{b}}$ & $0,033^{\mathrm{a}}$ & $0,040^{\mathrm{a}}$ \\
\hline & + & $(2,45)$ & $(2,12)$ & $(2,76)$ & $(2,47)$ & $(2,59)$ & $(2,20)$ \\
\hline \multirow{2}{*}{ LnVM } & + & $-0,005$ & $-0,002$ & $-0,004$ & 0,005 & $-0,005$ & 0,006 \\
\hline & + & $(-0,86)$ & $(-0,20)$ & $(-0,61)$ & $(0,49)$ & $(-0,68)$ & $(0,36)$ \\
\hline \multirow{2}{*}{ LnBTM } & & 0,006 & 0,023 & $-0,007$ & 0,004 & 0,002 & $-0,005$ \\
\hline & $\begin{array}{lll}- & - \\
-1 & \end{array}$ & $(0,77)$ & $(1,55)$ & $(-0,91)$ & $(-0,01)$ & $(0,17)$ & $(-0,43)$ \\
\hline \multirow{2}{*}{ Leverage } & & $0,097^{b}$ & $0,121^{\mathrm{c}}$ & 0,005 & 0,018 & 0,060 & 0,049 \\
\hline & + & $(2,22)$ & $(1,94)$ & $(0,12)$ & $(0,28)$ & $(1,08)$ & $(0,59)$ \\
\hline \multirow{2}{*}{ RA } & + & $0,072^{\mathrm{a}}$ & $0,054^{\mathrm{a}}$ & $0,085^{\mathrm{a}}$ & $0,084^{\mathrm{a}}$ & $0,054^{\mathrm{a}}$ & $0,045^{\mathrm{c}}$ \\
\hline & + & $(5,35)$ & $(2,68)$ & $(5,64)$ & $(3,71)$ & $(2,80)$ & $(1,74)$ \\
\hline
\end{tabular}




\begin{tabular}{|c|c|c|c|c|c|c|c|}
\hline \multicolumn{8}{|c|}{ Table 3 cont. } \\
\hline HT & - & $\begin{array}{l}-0,031 \\
(-1,19)\end{array}$ & $\begin{array}{l}-0,034 \\
(-0,78)\end{array}$ & $\begin{array}{l}-0,030 \\
(-1,17)\end{array}$ & $\begin{array}{l}0,010 \\
(0,22)\end{array}$ & $\begin{array}{l}-0,053^{\mathrm{c}} \\
(-1,73)\end{array}$ & $\begin{array}{l}-0,048 \\
(-0,96)\end{array}$ \\
\hline IND & - & $\begin{array}{r}-0,010 \\
(-0,34)\end{array}$ & $\begin{array}{l}0,011 \\
(0,22)\end{array}$ & $\begin{array}{l}-0,005 \\
(-0,18)\end{array}$ & $\begin{array}{l}0,079 \\
(1,57)\end{array}$ & $\begin{array}{l}-0,054 \\
(-1,44)\end{array}$ & $\begin{array}{l}0,025 \\
(0,43)\end{array}$ \\
\hline Buble & - & $\begin{array}{c}-0,008^{\mathrm{b}} \\
(-2,40)\end{array}$ & $\begin{array}{l}-0,003^{\mathrm{b}} \\
(-2,10)\end{array}$ & $\begin{array}{l}-0,034^{\mathrm{c}} \\
(-1,71)\end{array}$ & $\begin{array}{l}-0,045^{\mathrm{c}} \\
(-1,85)\end{array}$ & $\begin{array}{l}-0,044^{\mathrm{c}} \\
(-1,83)\end{array}$ & $\begin{array}{l}-0,062^{\mathrm{c}} \\
(-1,69)\end{array}$ \\
\hline $\mathrm{VC}$ & - & $\begin{array}{c}-0,074^{\mathrm{a}} \\
(-3,70)\end{array}$ & - & $\begin{array}{l}-0,050^{a} \\
(-2,54)\end{array}$ & 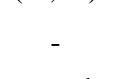 & $\begin{array}{l}-0,035 \\
(-1,42)\end{array}$ & , \\
\hline Rep & + & $(5, \pi)$ & $\begin{array}{l}0,049^{\mathrm{b}} \\
(2,42)\end{array}$ & ( & $\begin{array}{l}0,075^{\mathrm{b}} \\
(2,19)\end{array}$ & $(x, 12)$ & $\begin{array}{l}0,047 \\
(1,17)\end{array}$ \\
\hline Number Obs. & & 260 & 130 & 225 & 127 & 225 & 114 \\
\hline$R^{2}$ & & 0,24 & 0,19 & 0,23 & 0,25 & 0,14 & 0,17 \\
\hline$R^{2}$ ajustée & & 0,19 & 0,12 & 0,20 & 0,19 & 0,10 & 0,10 \\
\hline$F$-statistic & & $7,177^{\mathrm{a}}$ & $2,798^{\mathrm{a}}$ & $7,272^{\mathrm{a}}$ & $3,874^{\mathrm{a}}$ & $3,555^{\mathrm{a}}$ & $2,136^{\mathrm{a}}$ \\
\hline P-Value & & 0,000 & 0,000 & 0,000 & 0,000 & 0,000 & 0,000 \\
\hline
\end{tabular}

The dependant variable is the operational result deflated by total assets expressed in percentage, observed in a first 'full' sample that includes all the firms (Specification 1) and a second sample that comprises just the CVC (Specification 2). This performance measure is calculated for the year of the stock market launch (Year 0) and the two following years (Year 1 and Year 2). The list of firms includes CVC and non CVC launched on the French market between 1996 and 2007. The independent variables are: Bubble, a binary variable that takes value 1 if the firm in question was launched during the period 1998-2000 and zero otherwise; $H T(I N D)$, a binary variable which takes value 1 if the firm is listed in the hightech sector (the industrial sector) and zero otherwise; $R I$, the initial return realised during the first day of flotation; Leverage, a financial leverage which corresponds to the relation between the accounting value of liabilities and the accounting value of total assets; LnAGE, the logarithm of the age of the firm calculated by the difference between the date of creation and the date of the IPO; LnBTM, the logarithm for the Book-to-Market ratio (accounting value that compares the book value with the market value) of the firm when it launches the IPO; LnMV, the logarithm of the market value at the date of the flotation; Asset turns, which represent the turnover ratio deflated by total assets for the year in question; $V C$, a binary variable that takes value 1 if the firm is financed by VCF and zero otherwise; Rep, a dichotomous variable that takes value 1 if the CVC is supported by a reputed VCF and zero otherwise. $R A$, the rate of asset turns calculated for the year (-1). All of the linear regressions are estimated by the MGC method 'a, 'b' and 'c': significant tests are respectively at the thresholds of $1 \%, 5 \%$ and $10 \%$.

Respect to the leverage impact on operational performance, the results show that the explanatory power of this variable is confirmed uniquely in the year of the IPO launch. This limited impact may be explained by the arrival of new information and the development of a market history in the following financial years for the firms launched.

It should be noted that the coefficient associated with the age variable is significant at conventional thresholds for all the periods included. Actually, the age of firms launched on the market has a positive impact on the level of operational performance. However, the coefficients estimated by the regression model are low, which reduces their explanatory power regarding the post-IPO performance. Moreover, we observe that the operational performance of CVC is more sensitive to this variable compared to the results of the overall sample. These findings are in line with the observations by Rindermann (2003) based on a sample of European CVC.

We also observed a significant negative relation between the operational performance and market conditions (bubble years), confirming the "window of opportunity" theory formulated by Loughran \& Ritter (1995) and Ritter (1991). However, the low coefficient values enable us keep the impact of the launch period in perspective. These observations are similar for both samples (overall sample and CVC) for all the windows considered. Brav \& Gompers (1997) confirm the conclusions regarding the 'market timing' impact on the performance of firms launching an IPO. They found that the years marked by high IPO activity coincided with significant underperformances. Lerner (1994), however, explains this negative correlation by a behavioural approach of VCF, suggesting that the VCF are more effective at the time of the IPO and take advantage of the favourable market conditions.

In addition, we noted that the AT (asset turns) variable calculated over the course of the year prior to the IPO had a statistically significant positive impact on the operational performance of firms listed on the stock market for all the regressions estimated. Thus, firms that report a better ratio of asset turns pre-IPO manage to reduce the decline in their performance following flotation. In other words, the higher the performance of firms in the pre-IPO period, the better the operational performance will be. This is coherent with the economic climate theory put forward by Ljungqvist et al. (2006). These results also support the expected profitability theory advanced by Pastor \& 
Veronesi (2005). Regarding the issuers, this seems to confirm the notion that managers are careful to choose the best launch date.

Our findings also show that the negative coefficient of the VC variable is statistically significant at a threshold of $1 \%$ in years (0) and (1). This suggests that the presence of a VCF in the firm's capital at the time of the launch contributes to the decline in the performance of CVC, confirming the difference in performance observed in the univariate study on static data. Our results are in line with Ridermann's conclusions (2003) which found a negative correlation between the post-launch profitability of firms listed on the European markets and the presence of a VCF in the capital of these firms. Thus, the decline in CVC performance may in part be explained by the adverse selection theory.

To check the hypothesis of certification and the quality of VCF support, we introduced the Rep variable in the estimated regressions. We observed that the coefficient attached to this variable is positively significant at a threshold of 5\% during the first two years. This means that the support of reputed VCF helps to reduce the poor performance of CVC post-IPO. These observations concur with the conclusions of Ivanov et al. (2009) who explain the positive correlation between post-IPO performance and the reputation of VCF by two factors: (1) the high selectivity of projects by reputed VCF when selecting funding opportunities (see Ivanov et al., 2009) and (2) greater involvement in the management and control of CVC during the different phases of development and even after the IPO (see Gompers \& Lerner, 1998; Field \& Hanka, 2001; Baker \& Gompers, 2003).

Some variables display non significant coefficients at conventional thresholds for the windows selected in the study. This is true of the Book-to-market (BTM) and Value-to-market (VM) variables, which capture the size impact of the firm at the time of the IPO. This suggests that the firm's size has no impact on the decline in profitability, a result that goes against that of Brav \& Gompers (1997) in the American context and Rindermann (2003) in the European context.

Finally, in line with Wood et al. (2007), we tested the impact of the market sector on operational performance following the IPO. Unlike these authors, we did not find that the high-tech and industry sectors explained the decline in performance of firms listed on the French market in the different periods studied.

It is interesting to note that the quality of the regression models adjustment is relatively good, with an adjusted $\mathrm{R}^{2}$ between $10 \%$ and $19 \%$. However, the presence of constants that are significantly different to zero for some specifications shows that other variables could help to explain post-launch performance.

\section{Robustness of the Results}

In the following section, we propose a series of measures used to test the robustness of the results put forward in the preceding analysis. In the first stage, we tested the model using different performance measures such as economic margin, profit margin (assuming that the net result is corrected by the extraordinary elements) and rate of asset turns. ${ }^{6}$ However, in general the findings correlate with preceding conclusions. In the second stage, we used dynamic operational performance measures (Jain \& Kini, 1995; Wood et al., 2007; Ivanov, 2009). ${ }^{7}$ Once again, the findings concur with the conclusions detailed earlier, although we observed that the launch's timing has a positive impact on post-IPO performance variations. In the same way, the presence of a VCF in the capital of a CVC helps to limit the decline in post-IPO profitability. This appears to fit in with the evidence put forward by Jain \& Kini (1995) on the American market and Wood et al. (2007) on the UK market.

\section{CONCLUSION}

Several empirical studies have analysed the profitability of CVC launched on the stock market and have tried to make a connection with the presence of VCF in their capital during the operation. The studies mainly focus

\footnotetext{
${ }^{6}$ We replaced the level of asset turns as a pre-IPO performance indicator in the year prior to the IPO by the level of profitability.

${ }^{7}$ We calculated the explanatory variable coefficients of the performance variation calculated in relation to the year of the IPO: [0 to 1$]$ and [0 to 2].
} 
on the American and the British markets, with the exception of one study on the French market produced by Rindermann (2005) that developed a comparison with other European markets (German and British). The aim of our research is to present and explain the profitability of CVC launched on the French market in the period 1996-2007. To this end, we took a sample of $146 \mathrm{CVC}$ that we paired with 146 benchmark firms listed on the French market in line with sectorial and temporal criteria.

We identified the phenomenon of decline in operational performance of CVC launched on the stock market in the different periods, observing a decline in profitability ranging between $-9.47 \%$ and $-31.97 \%$ during the period of $(-1 ; 2)$. This decline is confirmed irrespective of the launch period or in the market sector. These findings concur with studies conducted on the American and British markets. However, the Wilcoxon non parametric significance test was inconclusive for all the windows selected. On the other hand, the performance comparison between the $\mathrm{CVC}$ and the benchmark firms shows a negative and significant difference during the year preceding the IPO and the year following the IPO. The division of our samples according to the IPO period (Internet bubble years and normal years) confirms the operational underperformance of CVC compared to non CVC. Unlike Wood et al. (2007), we did not find a significant difference between the listed CVC and the benchmark firms in the high-tech sector.

The multivariate regression model enabled us to identify a negatively significant correlation between profitability and the initial undervaluation in relation to the price of the offer. We also found a negative impact of the launch period which reinforced the underperformance of CVC during the bubble years. These results are in line with the developmental finance theory proposed by Loughran \& Ritter (1995), Krigman et al. (1999) and Ljungqvist et al. (2006). We can conclude that the CVC, particularly the less successful ones, launched an IPO to take advantage of the irrational behaviour of investors during the Internet bubble years.

The results are also inconclusive regarding the certification theory for the whole CVC sample. The estimated coefficients show that the presence of VCF in the firms' capital has a negative impact on post-IPO profitability. This result offers indirect proof of adverse selection. However, the reputation of VCF improves the performance of CVC during the flotation period. Globally, our results offer additional proof regarding the important role played by VCF in the funding of start-ups, especially in the first years a firm becomes public.

Our study has implications both for managers of CVC launching an IPO and for investors. Managers of firms who wish to launch an IPO in a volatile market should opt for the support of reputed VCF. The presence of a reputed VCF may be interpreted as a positive signal that reassures investors regarding the quality of the newly listed CVC (Ivanov, 2009). From a practical point of view, the present study shows that the reputation of VCF, as well as the pre-IPO performance level, may be used, along with other variables, to forecast the future performance of CVC launching an IPO, at the same time enabling us to analyse the conditions that favour an IPO's success. In addition, the study's use of Wilcoxon non parametric tests provides a useful methodological addition.

Finally, our results may depend on the level of performance of observations in the sample; the use of measures adjusted by the impact of the average and/or measures adjusted by sectorial median helped us to reinforce the robustness of our results. Similarly, the inclusion of factors describing changes in risk of firms listed on the Stock Market can help improve our understanding of a decline in operational performance. Longer term profitability ( 5 years) is also worth studying. The impact of the firm's shareholder structure and the association of bankers' and audit agencies' reputation could also offer interesting perspectives for further research.

\section{AUTHOR INFORMATION}

Moez Khalfallah is an assistant professor at CNAM-LISE (Paris). He is a specialist in venture capital and quantitative studies.

Bruno-Laurent Moschetto is an associate professor at the University of Valenciennes, IDP-LARIME. He is a specialist in quantitative finance and asset management. 
Frédéric Teulon is Head of the Research Center (IPAG Research Lab) and has made a career as a professor at various universities in Paris. He now teaches at the IPAG Business School (Paris and Nice). His main research areas are macroeconomics and international finance. E-mail: f.teulon@ipag.fr (Corresponding author)

\section{REFERENCES}

1. Allen, F., \& Faulhaber, G. (1989). Signalling by underpricing in the IPO market. Journal of Financial Economics, 23, 303-324.

2. Baker, M., \& Gompers, P. (2003). The determinants of board structure at the initial public offering. Journal of Law and Economics, 46, 569-598.

3. Barber, B. M., \& Lyon, J. D. (1996). Detecting abnormal operating performance: The empirical power and specification of test statistics. Journal of Financial Economics, 41, 359-399.

4. Brav, A., \& Gompers, P. A. (1997). Myth or reality? The long-run underperformance of initial public offerings: Evidence from venture and nonventure capital-backed companies. The Journal of Finance, 52(5), 1791-1821.

5. Espenlaub, S., Garrett, I., \& Mun, W. P. (1999). Conflicts of interest and the performance of venturecapital-backed IPOs: A preliminary look at the UK. Venture Capital, 1(4), 325-349.

6. Field, L., \& Hanka, G. (2001). The expiration of IPO share lockups. Journal of Finance, 56, 471-500.

7. Gompers, P. A., \& Lerner, J. (1999). What drives venture capital fundraising? (NBER Working Papers 6906). National Bureau of Economic Research.

8. Gompers, P. A. (1996). Grandstanding in the venture capital industry. Journal of Financial Economic, 43, 133-156.

9. Grinblatt, M., \& Hwang, C. (1989). Signalling and the pricing of new issues. Journal of Finance, 44(2), 393-420.

10. Hall, B., \& Lerner, J. (2010). The financing of R\&D and innovation. In B. Hall \& N. Rosenberg (eds), Handbook of economics of innovation. North Holland: Elsevier.

11. Harris, R., Murray, G., \& Niu, D. (2006). The operating performance of buyout IPOs in the UK and the influence of private equity financing. (Working paper). University of Exeter.

12. Hege, U., Palomino, F., \& Schwienbacher, A. (2003). Determinants of venture capital performance: Europe and the United States. Risk Capital and the Financing of European Innovative Firms.

13. Hellmann, T., \& Puri, M. (2002). Venture capital and the professionalization of start-up firms: Empirical evidence. Journal of Finance, 57(1), 169-97.

14. Ivanov, V., Krishnan, C., Masulis, W., \& Singh, K. (2009). Venture capital reputation and post-IPO performance. New Orleans Meetings Paper.

15. Jain, B., \& Kini, O. (1994). The post-issue operating performance of IPO firms. Journal of Finance, 49(5), 1699-1726.

16. Jain, B., \& Kini, O. (1995). Venture capitalist participation and the post-issue operating performance of IPO firms. Managerial and Decision Economics, 16(6), 593-606.

17. Jelic, R., Saadouni, B., \& Wright, M. (2005). Performance of private to public MBOs: The role of venture capital. Journal of Business Finance \& Accounting, 32, 643-681.

18. Jensen, M., \& Meckling, W. (1976). Theory of the firm: Managerial behavior, agency costs and ownership structure. Journal of Financial Economics, 3(4), 305-360.

19. Jensen, M. (1986). Agency costs of free cash flow, corporate finance, and takeovers. American Economic Review, 76(2), 323-329.

20. Jung, K., Kim, C., \& Stulz, R. (1996). Timing, investment opportunities, managerial discretion, and the security issue decision. Journal of Financial Economics, 159-185.

21. Krigman, L., Shaw, W., \& Womack, K. (1999). The persistence of IPO mispricing and the predictive power of flipping. Journal of Finance, 54(3), 1015-44.

22. Landier, A. (2001). Start-up financing: Banks vs. venture capital. Mimeo MIT.

23. Lantz, J.-S., Sahut, J.-M., \& Teulon, F. (2011). What is the real role of corporate venture capital? International Journal of Business, 16(4), 367-382.

24. Lee, P., \& Wahal, S. (2004). Grandstanding, certification and the underpricing of venture backed IPOs. Journal of Financial Economics, 73, 375-407. 
25. Lerner, J. (1994b). Venture capitalists and the decision to go public. Journal of Financial Economics, 35, 293-316.

26. Lin, T., \& Smith, R. (1998). Insider reputation and selling decisions: The unwinding of venture capital investments during equity IPOs. Journal of Corporate Finance, 4(3), 241-263.

27. Ljungqvist, A., Nanda, V., \& Singh, R. (2006). Hot markets, investor sentiment, and IPO pricing. Journal of Business, 79, 1667-1702.

28. Loughran, T., \& Ritter. J. (1995). The new issues puzzle. Journal of Finance, 50(1), 23-51.

29. Loughran. T., \& Ritter. J. (1997). The operating performance of firms conducting seasoned equity offering. Journal of Finance, 52, 1823-1850.

30. Megginson, W., \& Weiss, K. A. (1991). Venture capitalists certification in initial public offering. Journal of Finance, 46, 879-903.

31. Mikkelson, W., Partch, M., \& Shah, K. (1997). Ownership and operating performance of companies that go public. Journal of Financial Economics, 44(3), 281-308.

32. Miller, E. (1977). Risk, uncertainty and divergence of opinion. Journal of Finance, 32(4), 1151-1168.

33. Mulcahy, D. (2013). Six myths about venture capitalists. Harvard Business Review. May.

34. Nahata, R. (2008). Venture capital reputation and investment performance. Journal of Financial Economics, 90(2), 127-151.

35. Ofek, E., \& Richardson, M. (2002). The valuation and market rationality of internet stock prices. Oxford Review of Economic Policy, 18(3), 265-287.

36. Pastor, L., \& Veronesi, P. (2005). Rational IPO waves. Journal of Finance, 60(4), 1713-1757.

37. Rindermann, G. (2003). Venture capitalist participation and the performance of IPO firms. Empirical evidence from France, Germany and the UK. European University Studies, 3029.

38. Ritter, J. (1991). The long-run performance of initial public offerings. Journal of Finance, 42, 365-394.

39. Sapienza, H., Manigart, S., \& Vermeir, W. (1996). Venture capitalist governance and value added in four countries. Journal of Business Venturing, 11, 439-469.

40. Sentis, P. (2011). Les performances opérationnelles et boursières des introductions en Bourse: Le cas français 1991-1995. Finance, 22, 87-118.

41. Tian, X. (2012). The role of venture capital syndication in value creation for entrepreneurial firms. Review of Finance, 16(1), 245-283.

42. Timmons, J., \& Bygrave, W. (1986). Venture capital's role in financing innovation for economic growth. Journal of Business Venturing, 1, 161-176.

43. Wood, A., Coakley, J., \& Hadass, L. (2007). Post-IPO operating performance, venture capital and the bubble years. Journal of Business Finance \& Accounting, 34, 1423-1446.

44. Wright, M., Manigart, S., De Waele, K., Robbie, K., Sapienza, H., \& Beekman, A. (2002). Determinants of required return in venture capital investments: A five country study. Journal of Business Venturing, 17, 291-312. 


\section{APPENDIX}

Classification of SCR According to the Amount Invested in the French Market in the EVC

\begin{tabular}{lc}
\hline \multicolumn{1}{c}{ SCR } & Market Share (\%) \\
\hline Management & 12,5 \\
Siparex Group & 8,0 \\
Credit Agricole & 5,4 \\
3i Group PLC & 4,5 \\
Innovacom & 3,4 \\
CDC Entreprises Innovation & 3,3 \\
Sofinnova Partners & 3,1 \\
Naxicap Partners & 2,7 \\
AXA Private Equity & 2,7 \\
Banque De Vizille & 2,7 \\
\hline
\end{tabular}




\section{NOTES}

